\title{
Interaction between Rural People's Basic Needs and Forest Products: A Case Study of the Katha District of Myanmar
}

\author{
Zar Chi Hlaing, Chiho Kamiyama, and Osamu Saito \\ United Nations University Institute for the Advanced Study of Sustainability (UNU-IAS), \\ 5-53-70 Jingumae, Shibuya-ku, Tokyo 150-8925, Japan \\ Correspondence should be addressed to Zar Chi Hlaing; zarchihlaing08@gmail.com
}

Received 27 June 2017; Accepted 6 September 2017; Published 30 October 2017

Academic Editor: Kihachiro Kikuzawa

Copyright (C) 2017 Zar Chi Hlaing et al. This is an open access article distributed under the Creative Commons Attribution License, which permits unrestricted use, distribution, and reproduction in any medium, provided the original work is properly cited.

The understanding of interaction between rural people and forest products is one of the challenges faced while balancing forest product utilization with forest conservation in Myanmar. This study aims to contribute an effort to such challenges by analyzing the interaction of rural households with forest products in Myanmar. Data were collected using face-to-face questionnaire interviews with 218 households and conducting a rapid tree inventory across 132 circular random plots in selected rural communities around four townships of the Katha District. The empirical results indicate that the $95 \%$ of rural households were entirely dependent on forest products. The survey documented 13 main forest products and 54 tree species, which were primarily used for household consumption. Low-income households compared with medium- and high-income households with low educational level $(p<0.05)$ and a small agricultural land area $(p<0.05)$ were found to be more forest-dependent households. Illegal logging, mining, fuelwood collection, slash-and-burn agriculture, and the establishment of forest plantations were reported as the main causes of forest products depletion. Findings from this study, although at a microlevel, can be used by the Myanmar Forestry Department as baseline information to improve community-based forest management activities.

\section{Introduction}

Globally, about 1.6 billion rural people's livelihood depends fully or partially on products derived from local forests $[1,2]$. These people live within or adjacent to the forest and have relied on these wild and natural resources to meet their basic needs for survival and livelihoods for many generations [1]. Several studies [2-4] highlight the significant contributions of forest products to the income of rural households, including the alleviation of poverty [5]. This dependence has indicated negative impacts on the environment such as forest resource depletion, soil erosion, water pollution, and climate change [1]. In Myanmar, a developing country, $70 \%$ of the total population comprises rural households living close to the forest and depending on it for their livelihoods [6-8]. This population practices shifting cultivation in the nearby forest area and directly extracts forest products $[9,10]$. According to the findings of Forest Resource Assessment, Myanmar has the third highest rate of annual forest area reduction in the world [11], lost due to several factors including increasing population, poverty, and unsustainable land-use practices $[6,11-13]$.

To address the negative impacts of the people-forest interaction, forest conservation has become an important course of action with the maintenance of diverse natural habitats through regulation of people's access to and utilization of forest products [13-15]. Conservation proponents argue that formal forest conservation actions provide the best possible way to achieve resource sustainability [16-18]. They also point out that only a small fraction of people doubts the potential of forest conservation to alleviate poverty among users [17, 19]. However, several challenges have emerged regarding the ways of creating a balance between forest conservation and utilization without compromising on ecological values, especially in developing countries [20,21]. The understanding of the interaction between people and forests is imperative to address the challenges $[16,22]$ that comprise people's perceptions about their local ecosystem as one critical factor [23]. A deeper understanding of the people-forest interaction at the community level is limited, and necessary to achieve 
an effective, long-term forest conservation strategy that generates benefits to local people's livelihoods through policy interventions $[24,25]$ because rural people's dependence on forest products varies across regions [20,21].

Myanmar forests are socially and economically significant to the country. Since 1856, the government of Myanmar has applied forest management principles to conserve its forests for the sustainability of forest products $[26,27]$. The community-based forest management (CBFM) approach was introduced in the 1990s. The Forest Law of 1992, Myanmar Forest Policy of 1995, the Protection of Wildlife \& Wild Plants and Conservation of Natural Areas Law of 1994, and Community Forestry Instructions of 1995 were issued by the government and are enacted to achieve sustainable forest management [7]. The Forest Department of Myanmar (FD) conducts the national forest inventory as a forest resource accounting system to assess the forest condition and landuse changes to develop stand and volume tables [28]. On the basis of this information, the FD is conducting a working plan with the activities of forest conservation and development for both environment and people to achieve sustainable forest management. The Forest Law of 1992 stipulates that local communities, who live in the forest land area, have a right to use the forest products from their surrounding areas for their consumption (domestic uses). It also defines the extraction quantity of forest products based on the available stock of resources. The local communities are not allowed to trespass and/or encroach rights, pasture, break up, clear, dig, or damage the original condition of the forest land without a permission from the government [7]. The FD imposes a seasonal hunting restriction to protect the wildlife based on the Protection of Wildlife \& Wild Plants and Conservation of Natural Areas Law of 1994. Despite these efforts, Myanmar lost 19\% of its forest area between 1990 and 2010 [8]. The weak enforcement of regulations regarding the implementation of forest conservation and utilization activities have emerged as a critical problem for sustainable forest management $[6,14,26,27]$. Although the FD applies the CBFM approach to conserve the forests, information on rural people's interaction with forest products is not available, and, as a result, it has not been incorporated into the relevant policies and management plans [6]. This negligence has been largely limited to descriptive accounts of people's interaction with forest products [29]. This oversight has created a gap in knowledge on people's interaction with forest products and is one of the major challenges for balancing forest conservation with the sustainable utilization of forest products for rural livelihood $[12,15,30]$. The understanding of people's dependence on forest products can bridge this gap and can support the activities of conservation and development policy interventions as sustainable forest management [31].

The objective of this study is to analyze how rural people interact with forest products to meet their daily basic needs through a case study of rural communities in the Katha District of Myanmar. In the study, the basic needs of rural people mainly refers to food, energy, shelter, income, and healthcare [32,33], while forest products refer to any product derived from forests, other wooded lands, and trees outside forests for subsistence use or cash generation. These forest products include timber, nontimber, and wild animals and their by-products $[8,10]$. Furthermore, the study attempts to assess how household characteristics may influence people's dependence on forest products and evaluates their utilized species composition and their perceptions about surrounding forests.

\section{Materials and Methods}

2.1. Study Area. The study was conducted in the Katha District of Myanmar, located between $23^{\circ} 31^{\prime}$ and $24^{\circ} 57^{\prime} \mathrm{N}$ and $95^{\circ} 14^{\prime}$ and $96^{\circ} 17^{\prime} \mathrm{E}$. It is located between $200 \mathrm{~m}$ and $400 \mathrm{~m}$ above sea level, with highly humid weather (83.4\%), high average annual rainfall $(>4,000 \mathrm{~mm})$, and an average temperature of $38.6^{\circ} \mathrm{C}[10]$. The area is dominated by moist upper mixed deciduous forest and is classified as a Protected Public Forest under the management of the FD [10]. There are teak plantations established by the FD and registered gold mines of private companies within this forest area [10]. The district is one of the target areas of the FD for forest resource conservation through the integration of a forest conservation and development strategy. Specifically, four main townships-Banmauk (BM), Kawlin (KL), Pinlebu (PLB), and Wuntho (WT) - within the Katha District were selected for the field surveys as more than $89 \%$ of the total district population comprises rural populations living in these four townships [34] and $81 \%$ of theses townships' areas are covered with natural forest. According to the Myanmar Information Management Unit (MIMU), a township is the third-level administrative division and is the subdivision of the district. Both urban and rural areas falling within the administrative boundaries of a township were included.

In these four townships, 15 rural communities (BM: Pin Hin Khar, Tone Poke, Haw Yaw, and Nam Hyin; KL: Kyun Taw, Pulaw Kalone, Cheyar, and Ayigyi; PLB: Waelar, Kha Tet, Ywar Tharyar, and Chaung Phya; and WT: Kan Kone, Binga, and Kyun Pin) were selected for the final field survey (Figure 1). The rural communities were selected with purposive sampling on the basis of the following factors: a high rural population area in the township, the proximity of the rural settlements to forested areas and urban settlements, and village size (number of households in the village).

In the studied communities, the average household $(\mathrm{HH})$ size is 5.8 household members with a minimum of three and a maximum of fourteen persons living in one household. The average education level is primary school. Generally, $95 \%$ and $86 \%$ of the households are engaged in forest-related and agricultural activities, respectively, as their main livelihood. They have a settlement history of over 100 years in these forest areas. The current inhabitants share the same ancestry and have similar cultures and analogous social institutions. The forests were previously inhabited by the ancestors of the locals and believed that forest ownership is customarily passed through ancestry. The surrounding forest is confirmed to be natural forests dominated by broadleaf species such as Sagat (Quercus glauca), Teak (Tectona grandis), and In (Dipterocarpus tuberculatus). The settlements are located at an average distance of $2 \mathrm{~km}$ from their surrounding natural forest areas and $36 \mathrm{~km}$ from the nearest urban area (towns). 


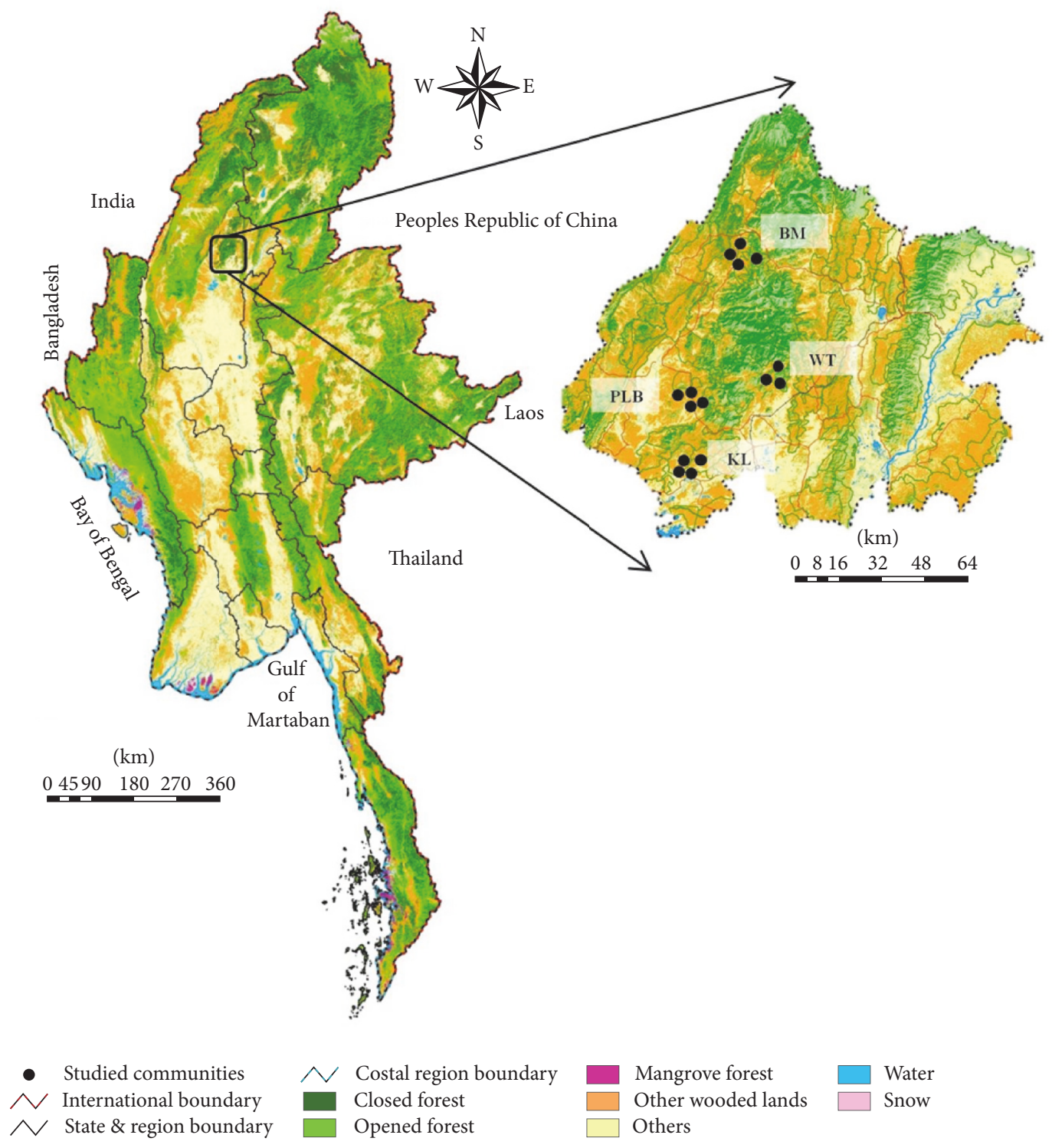

FIgURE 1: Location of studied communities. Source: Katha District Forest Department, 2015 [10].

The rural communities define their forest boundaries in the surrounding forest area. The determination of forest boundaries has traditionally been set through discussions among neighboring communities and community members based on the streams and the ridges in the forest area. Although these forest boundaries are not officially recognized by the government, the communities comply with them and collect forest products within their designated forest boundaries.

Shifting cultivation with rice, groundnut, sesame, and sunflower is found to be a common agricultural practice in the surrounding forests and the permanent farmland, with only rice present around the settlements. Although most of the households in the studied communities have their own land for living in the settlement area, they do not own land for cultivation, that is, ungranted land area [10]. Generally, agricultural and forest activities are carried out as seasonal activities for livelihood. Home gardens are found around their homes in which fruit (tomatoes, brinjal, chillies, peas, bitter gourd, and ribbed gourd), tubers (potatoes, sweet potatoes, and radish), bulbs (onions and garlic), papaya, banana, and guava are planted for consumption. Fruit trees [ $>0.1 \mathrm{~m}$ of diameter at breast height (DBH)] such as mango, tamarind, coconut, and betel nut are also found along roadsides of the settlements.

Animal husbandry with pigs, cattle, and buffaloes is practiced in the studied communities. Pigs are raised for income, while cattle or buffalo are mainly used to plow agricultural land. Occupations of people residing in the study area include daily labor work at farms of other households and in gold mines, work in small private shops, and government services such as elementary school teachers. 
2.2. Methods. Field-based quantitative and qualitative data collection was carried out in November 2015 and April 2016. We used an ethnobotanical approach [35] to achieve study objectives. This is a vital approach to study forest resource management and the interaction between people and forest products as it can evaluate the people, plants, and interaction of resource usage $[35,36]$. The community-entry meetings were started with the 10-20 community people such as village heads, village elders, and a few additional villagers to obtain a general overview of the villages. Next, key informants were identified for a series of in-depth interviews using a snowball sampling technique. Snowball sampling was used to identify and get more information about the forest products (where to get and the different types of products available in the forest), forest trees (knowledge on the trees' local name), their utilization (with different purposes), and surrounding forest areas. The target group for the key informants' interview was a group of elders aged over 65 years. Household interviews with a total of 218 households $(10 \%$ of the total households in the studied communities) were randomly sampled to investigate the interaction between the people and forest. Interviews were conducted with household heads $(\mathrm{HHH})$ and where unavailable, a suggested person was interviewed. The household survey questionnaire was developed using a semistructured format with both closed and open-ended questions to obtain information about $\mathrm{HH}$ characteristics (demographic factors, household assets including food sources), $\mathrm{HH}$ income conditions, the collected forest products, and their perceptions about the forest. These interviews took between 30 and 45 minutes per household.

2.2.1. Household Characteristics and Perception. HH characteristics were collected from the HHHs regarding the members' (family members or relatives who live, eat, and work together in the same house) age, sex, education level, occupation of HH's members, and the HH's activities for livelihood. The number of working people in $\mathrm{HH}$ was recorded for people aged between 15 and 75 years based on local conditions even though the working age range for working groups is defined by the Department of Labor of Myanmar as 15-65 years [37]. Education levels were categorized into six groups as per the categorization of the Myanmar National Education Law, 2014: 0 = no education (an inability to read or write), 1 = informal education (monastery), 2 = elementary school, 3 $=$ middle school, $4=$ high school, and $5=$ university level. To ascertain people's perceptions regarding the forest condition, they were asked closed and open-ended questions like "Do you think the surrounding forest area is changing? How has it changed?" Based on their answers, follow-up questions were added to inquire about the reasons behind their answer to the previous question and how the changing forest conditions affect their dependence on forest products to sustain their daily lives.

2.2.2. Household Income. HH income activities were divided into four groups: agriculture, forest products (timber forest products and nontimber forest products [NTFPs]), livestock, and other activities (daily labor wages, small private shops, and government services). Subsistence value is defined as the value of products consumed directly by the household or given away to friends and relatives $[4,38]$. $\mathrm{HH}$ annual income was calculated by combining the income from all $\mathrm{HH}$ activities for cash and subsistence that was based on recall for one year, that is, the previous year (see (1)). During the community-entry meetings, the villagers (all participants) were asked to categorize the incomes of their $\mathrm{HHs}$ into three annual income levels-high, medium, and low-on the basis of household daily (wages) net income. The reference exchange rate of the Myanmar Kyat (MMK) for accounting transactions against the US dollar (USD) was based on the exchange rate at the time of data collection, that is, 1,100 MMK = 1 USD. The low-income level was less than 792,000 MMK (approximately, 720 USD), the medium-income range was between 792,000 and 1,440,000 MMK (<1,309 USD), and the high-income level was higher than 1,440,000 MMK (approximately. >1,309 USD). HH size was adjusted to "adult equivalent units" on the basis of the coefficients for the adult equivalent system (frequently used by World Bank) [39, 40]. A nonparametric Kruskal-Wallis test was used to analyze the differences in income activities across different income levels.

$$
Y_{\mathrm{ti}}=\sum_{i=1}^{n}\left[s_{i}\right]
$$

where $Y_{\mathrm{ti}}$ is household annual total income and $s_{i}$ is the household activities.

Agricultural income was calculated by multiplying crop yields (the amount of crops the household sold for income and the number of crops they consume) and the reported prices of the sold crops by the households (within their settlement). The calculated agricultural income was assumed as net income because the input values such as seeds (only purchased crop seed was considered), fertilizer (only purchased fertilizer was considered), and labor cost (only additional hired labor cost was considered) were deducted from the total agricultural income [40].

Livestock income was calculated using the income stream formula proposed by Cavendish [40] that assumes the net present value of the entire future income stream (see (2)). Livestock income included income from the sale and consumption.

$$
Y_{0}=P_{0} \frac{r}{r-(1 /(1+r))^{T}+1},
$$

where $Y_{0}$ is the current year livestock income, $T$ is lifespan of the livestock measured from the current date (average lifespan is 1 year for pigs, 15 years for cow, and 20 years for buffalo in the study area), $r$ is the discount rate of $10 \%$ based on the local market conditions of the study area, and $P_{0}$ is the current price of a livestock unit based on household-reported price. The rate of mortality and loss of livestock were not considered in this present study.

The income from day labor wages, small private shops, and government services was included in calculating the income from other activities. Daily labor wages for men and women were not the same. The wage rate and the number of working days reported per household were used. Income 
from working in small private shops and government services was obtained from that individual household.

The types of forest products collected by the household were recorded. The income from forest products was calculated on the basis of subsistence and cash generation. The quantity and reported prices of forest products sold by each household were used for calculating forest income. The subsistence value of the collected forest products was calculated using a market-based approach. For the consumption of forest products such as vegetables, thatch, and fuelwood which are difficult to value, assumptions, omissions, or triangulation with the closest substituted prices were used. Timber for construction material and small wood for manufacturing cultivating tools (beam, wooden plow, and spade handle) were recorded as the type of forest products collected by communities. However, these products were not collected as part of the previous year data and were further excluded from the calculation of forest income. The quantity of collected fodder cannot be recalled by the communities and, hence, not considered in the calculation of forest income.

2.2.3. Forest Dependency. Forest dependency is defined and measured on the basis of overlapping categories such as the extraction and production of forest products and the economics of the use of "nonconsumptive" natural resources for tourism or amenities [9, 40-43]. Each of these benefits has a different relationship with people and is mediated by social structures that allow people to receive them [9, 40-43]. In this study, forest dependency is considered people's economic dependence on the forest $[15,44-48]$, specifically the forest net income and the collected varieties of forest products usually used by people to meet their basic needs such as subsistence. Ordinary least squares (OLS) regression was run to identify the influence of $\mathrm{HH}$ characteristics variables on the forest products. The collected varieties of forest products and forest net income were considered dependent variables. $\mathrm{HH}$ characteristics (household size, the number of people able to work, age, sex, and education level of $\mathrm{HHHs}$, agricultural land area, the number of livestock, and income from agriculture, livestock, and other activities) were considered independent explanatory variables. The analysis was conducted using the IBM SPSS 23 statistical package.

2.2.4. Forest Species Composition. At the community-entry meetings, we asked local people from the studied communities to identify their forest boundaries around their settlement where they usually collect forest products. This forest area was approximately 750 ha. A rapid inventory of tree species was conducted using circular random sample plots $\left(300 \mathrm{~m}^{2}\right)$. In total, 132 sample plots were inventoried with 38 in BM, 38 in WT, 29 in KL, and 27 in PLB, based on the defined forest areas for each studied community. All tree species in the sample plots were measured for total height and DBH. First, the locals recorded the local names of each species if they could identify it. Next, the botanical names were noted according to "Botanical exploration in Myanmar, 2003" [49]. Finally, the botanical names of the tree species were checked with the experts at the herbarium of the Forest Research Institute of Myanmar. If the experts could not verify a botanical name, it was listed as "unknown" and only the local name was recorded. Conducting forest inventory contributes in understanding the condition of collected trees as well as the forest (trees) compositions.

\section{Results}

3.1. Diversity of Forest Products Collected and Used by Households. Table 1 shows the diversities of forest products collected by $\mathrm{HHs}$, the estimated average annual collection, and their contribution to the different aspects of daily basic needs. Of the 13 main forest products identified, timber (96\%) is the most frequently collected, while orchids (14\%) were the least collected. Food, building materials, energy, medicine, and income are found to be the main uses. Below, we explore how these basic needs are derived from each of the forest products on the basis of interviews with HHHs, field observations, and key informants.

Food. All types of foods collected and consumed in each studied $\mathrm{HH}$ were observed and their quantities were recorded as long as the $\mathrm{HH}$ could recall. HHs collect forest products to use as vegetables such as edible leaves from trees, shrubs, flowers and seasonal fruits, mushrooms, bamboo shoots, honey, bush meat, and fodder for their livestock. These were used for both consumption and cash generation. Food products were mostly collected during the rainy season (from May to October).

Building Materials. Timber, thatch, and bamboo are used as different building materials components. These products were used for the floor, walls, poles, rafters, beams, roofs, and other parts of the houses. Bamboo was collected not only as a building material but also for cash generation. Although an overwhelming number of households use timber $(96 \%)$ and bamboo (82\%), for their houses in the study area, $33 \%$ of the HHs use thatch (Table 1). Nowadays, lowpriced zinc is available and it is sometimes used for roofing instead of thatch. Teak (Tectona grandis), In (Dipterocarpus tuberculatus), Ingyin (Shorea siamensis), and Tamalan (Dalbergia burmanica) were recorded to be the most frequently collected species for construction. Bamboo such as Tin-wa (Cephalostachyum pergracile) and Kyauthaung-wa (Bambusa polymorpha) and thatch such as palm leaves (Calamus spp.) and thetke grass (Imperata cylindrica) are mostly collected for roofing.

Tools. Small wood is collected for making or repairing cattle/ buffalo carts and agricultural cultivation tools such as plows, harrows, yokes, and spade handles. The most frequently collected tree species were Yemane (Gmelina arborea), Thitnet, and Yant-kaw (local names). Some collected small wood was also used as building material (timber) (Table 2).

Energy. The average annual fuel-wood consumption is approximately $3.4 \mathrm{~m}^{3}$ per household (Table 1) in the study area. Sagat (Quercus glauca) and Htaukkyant (Terminalia 
TABLE 1: Diversity in the collected forest products and their contribution to household's daily basic needs.

\begin{tabular}{|c|c|c|c|c|c|}
\hline \multirow[t]{2}{*}{ Number } & \multirow[t]{2}{*}{ Forest products } & \multirow{2}{*}{$\begin{array}{l}\text { Number of households } \\
\text { engaged in forest product } \\
\text { collection }(n=207)\end{array}$} & \multicolumn{2}{|c|}{$\begin{array}{l}\text { Average annual quantity of collected } \\
\text { forest products per household }\end{array}$} & \multirow[t]{2}{*}{$\begin{array}{l}\text { Direct contribution to daily } \\
\text { basic needs }\end{array}$} \\
\hline & & & Unit & Unit/year/household & \\
\hline$(1)$ & Timber $^{\mathrm{a}}$ & $198(96 \%)$ & $\mathrm{m}^{3}$ & - & Building materials, energy \\
\hline$(2)$ & Fuel-wood ${ }^{\mathrm{a}}$ & $185(89 \%)$ & $\mathrm{m}^{3}$ & $3.4( \pm 0.1)$ & Energy \\
\hline (3) & Fodder $^{\mathrm{a}}$ & $185(89 \%)$ & Grass bundle & - & Livestock feed \\
\hline$(4)$ & Bamboo $^{\mathrm{a}, \mathrm{b}}$ & $170(82 \%)$ & $\mathrm{Culm}^{\dagger}$ & $18.1( \pm 1.4)$ & Building materials, income \\
\hline$(5)$ & $\begin{array}{l}\text { Bamboo } \\
\text { shoots }^{\mathrm{a}, \mathrm{b}}\end{array}$ & $146(71 \%)$ & $\mathrm{kg}$ & $7.8( \pm 0.3)$ & Food, income \\
\hline (6) & Mushrooms ${ }^{\mathrm{a}, \mathrm{b}}$ & $129(62 \%)$ & $\mathrm{kg}$ & $2.3( \pm 0.1)$ & Food, income \\
\hline$(7)$ & Small wood ${ }^{\mathrm{a}}$ & $105(51 \%)$ & $\mathrm{m}^{3}$ & - & Tools, building materials \\
\hline$(8)$ & $\begin{array}{c}{ }^{*} \text { Food } \\
(\text { vegetables })^{\mathrm{a}}\end{array}$ & $85(41 \%)$ & $\mathrm{kg}$ & $3.9( \pm 0.2)$ & Food \\
\hline$(9)$ & $\begin{array}{l}\text { Medicinal } \\
\text { plants }^{\mathrm{a}, \mathrm{b}}\end{array}$ & $70(34 \%)$ & $\mathrm{kg}$ & $1.3( \pm 0.1)$ & Medicine, income \\
\hline$(10)$ & Thatch $^{\mathrm{a}}$ & $68(33 \%)$ & Panel $^{* *}$ & $91.0( \pm 19.1)$ & Building materials \\
\hline$(11)$ & Bush meat ${ }^{\mathrm{a}, \mathrm{b}}$ & $63(30 \%)$ & $\mathrm{kg}$ & $2.4( \pm 0.2)$ & Food, income \\
\hline$(12)$ & Honey ${ }^{\mathrm{a}, \mathrm{b}}$ & $41(20 \%)$ & Liter & $0.7( \pm 0.4)$ & Medicine, food, income \\
\hline (13) & Orchids ${ }^{\mathrm{a}, \mathrm{b}}$ & $28(14 \%)$ & $\mathrm{kg}$ & $1.1( \pm 0.3)$ & medicine, income \\
\hline
\end{tabular}

${ }^{\mathrm{a}}$ Subsistence products; ${ }^{\mathrm{b}}$ cash generation products; ${ }^{*}$ food (vegetables) $=$ edible leaves and flowers from trees, shrubs, flowers, and seasonal fruits; ${ }^{\dagger} 1 \mathrm{culm}=1$ stem of bamboo from the clump; ${ }^{* *} 1$ panel $=1$ thatch panel is $1.2 \mathrm{~m}$ in length and $0.7 \mathrm{~m}$ in height. It is woven from dried thetke grass; $( \pm)$ shows standard error.

crenulata) are commonly collected by the locals for fuelwood.

Medicine. The locals in the study area depend more on herbal medicines than western medicines. Sin-ton-manew (Tinospora cordifolia), Win-u (Millettia extensa), and Phanlan-taung-hmwe (Costus speciosus) were mostly collected for their medicinal values and were used in the treatments for illness, wounds, rheumatic swelling, and pain-relief massage. Although, on an average, 14\% of the households collect and sell orchids for income (Table 1), these are not collected only for their ornamental value but also to be as herbal medicine; Pan-yoe (Dendrobium spp.), especially, along with its stem, is used in the treatment of broken bones.

Distribution of Useful Tree Species. A total of 133 tree species were documented in the surrounding forests with 103 species identified by both their botanical names and local names. However, 30 species were not identified botanically and were recorded only according to their local names (Table 2). The surrounding forest areas could be mainly considered as secondary forests comprising $70 \%$ of small individual trees $(<0.1 \mathrm{~m} \mathrm{DBH})$ and $30 \%$ of large and mature trees $(>0.1 \mathrm{~m}$ $\mathrm{DBH})$. A total of 54 tree species ( $41 \%$ of total recorded species) were documented as frequently collected by local people as timber (24 species), cultivating tools (eight species), fuel-wood (22 species), food (such as thunder leaves, flower, fruits) (14 species), medicine (eight species), and other uses (such as wood oil, leaves for smoking, bark for weaving baskets) (seven species) (Table 2). 67\% of small individual trees are dominantly the surrounding forest. The presence of such a large percentage of small diameter trees indicated that the forests were at a level of succession that could be selfsustaining or could be due to a recurrent human disturbance on the growth pattern of the forests.

3.2. Contribution of Forest Products to the Subsistence and Cash Generation of HHs. Table 3 shows the contribution of collected forest products to the subsistence and cash generation of $\mathrm{HH}$. People depended over four times more on forest products for their direct consumption than for their cash generation on the basis of the monetary values of forest products. As timber, small wood, and fodder were not included in the estimation of annual monetary values, the estimated value is likely to be lower than the actual economic value of forest products. The estimation of income (cash generation) from forest products is mostly based on nontimber products.

Figure 2 shows the contribution of household income activities to total annual household income. Agricultural income was the highest contributor to total household income $(52 \%)$ followed by livestock income (31\%), other activities' income (11\%), and forest income (6\%). There were significant differences $(p<0.001)$ between cash income and total (cash and subsistence) income from agriculture, livestock, and forest, and local people are more dependent on agriculture and other activities for cash generation. The forest income was found to contribute the least to household income among all the income sources. If timber, small wood, fodder, and other forest products were included to calculate the forest product valuation, the forest income contribution could be higher than the estimated value in this study.

Table 4 illustrates household activities and their (cash) contributions by different income categories. The highest 


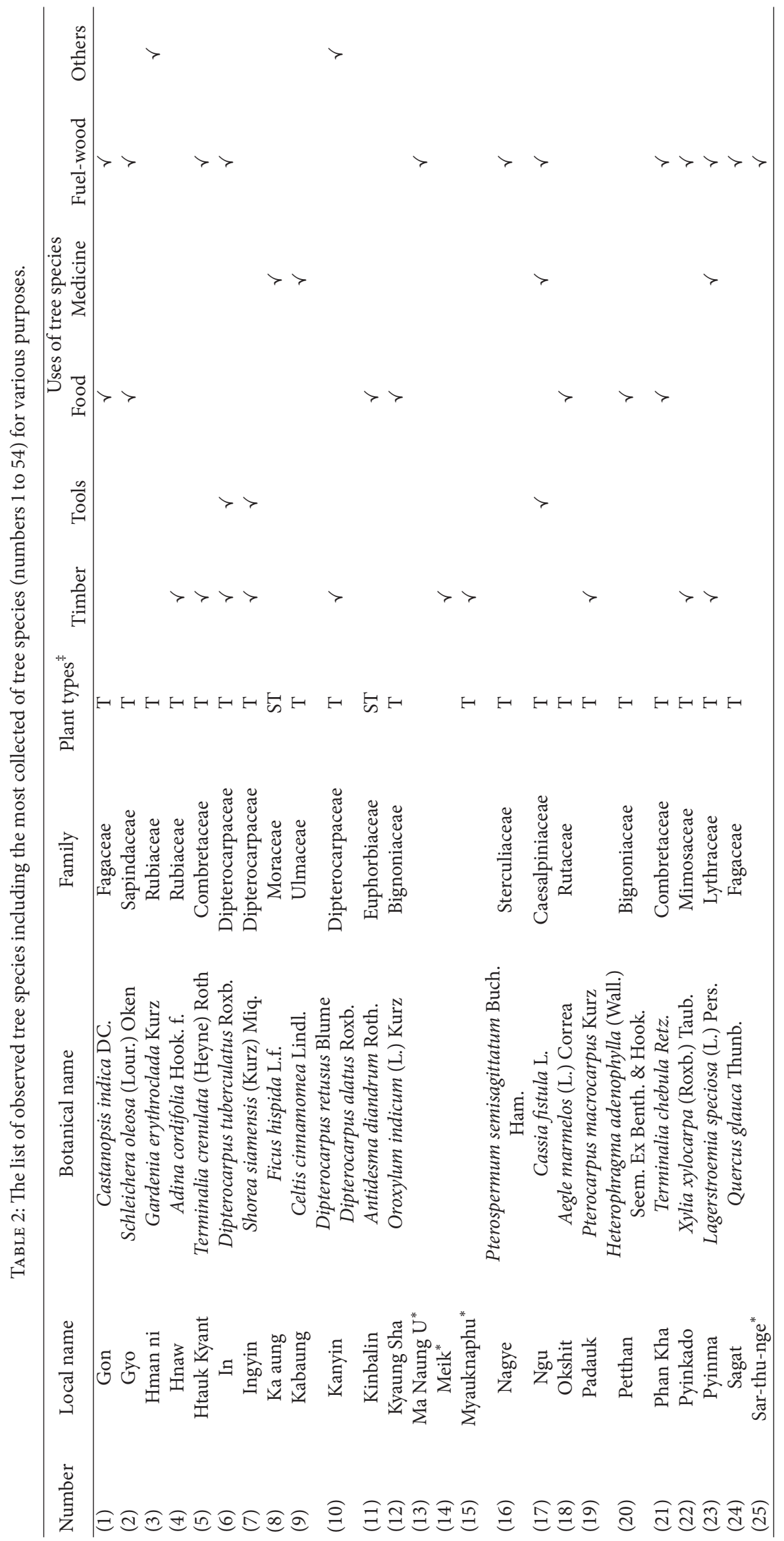




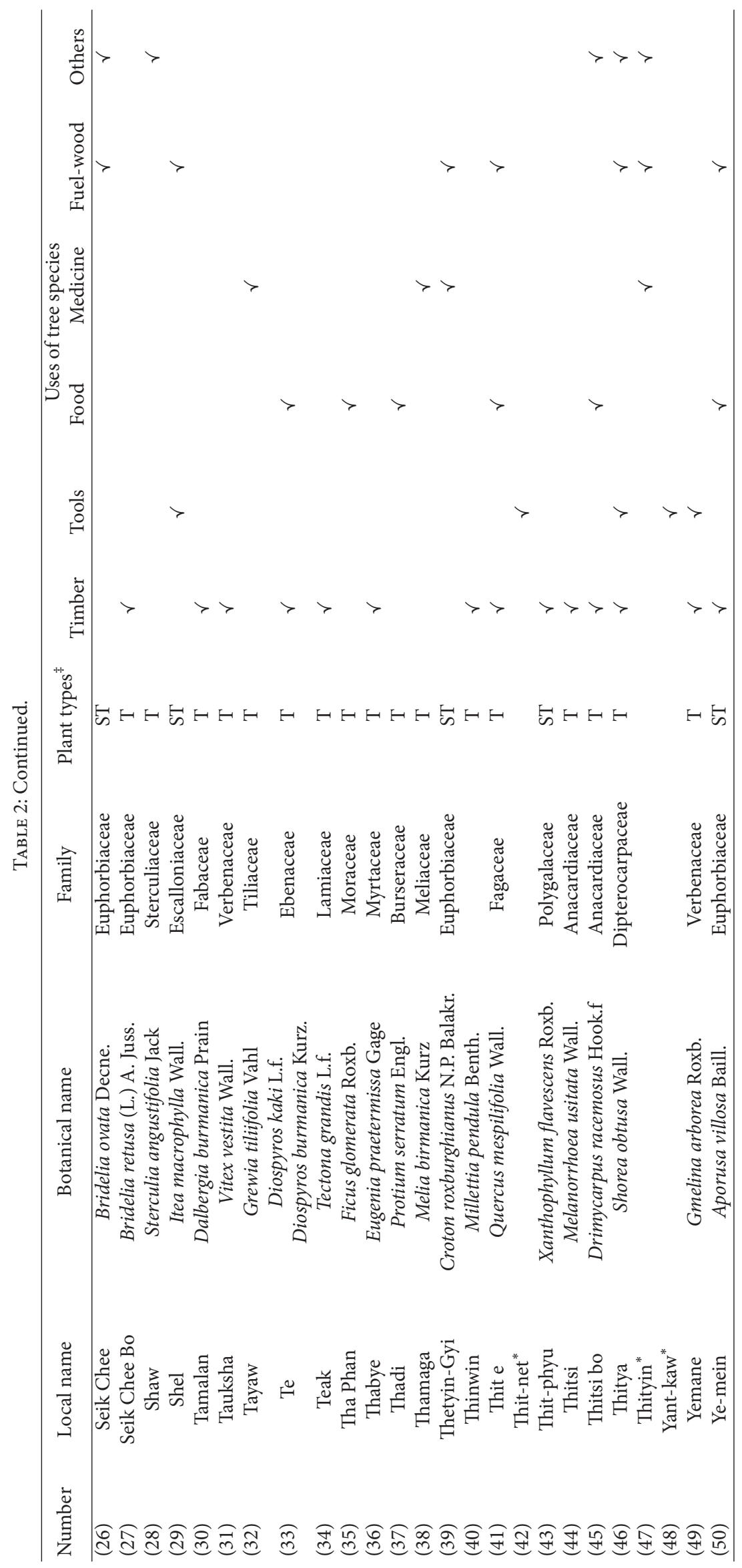




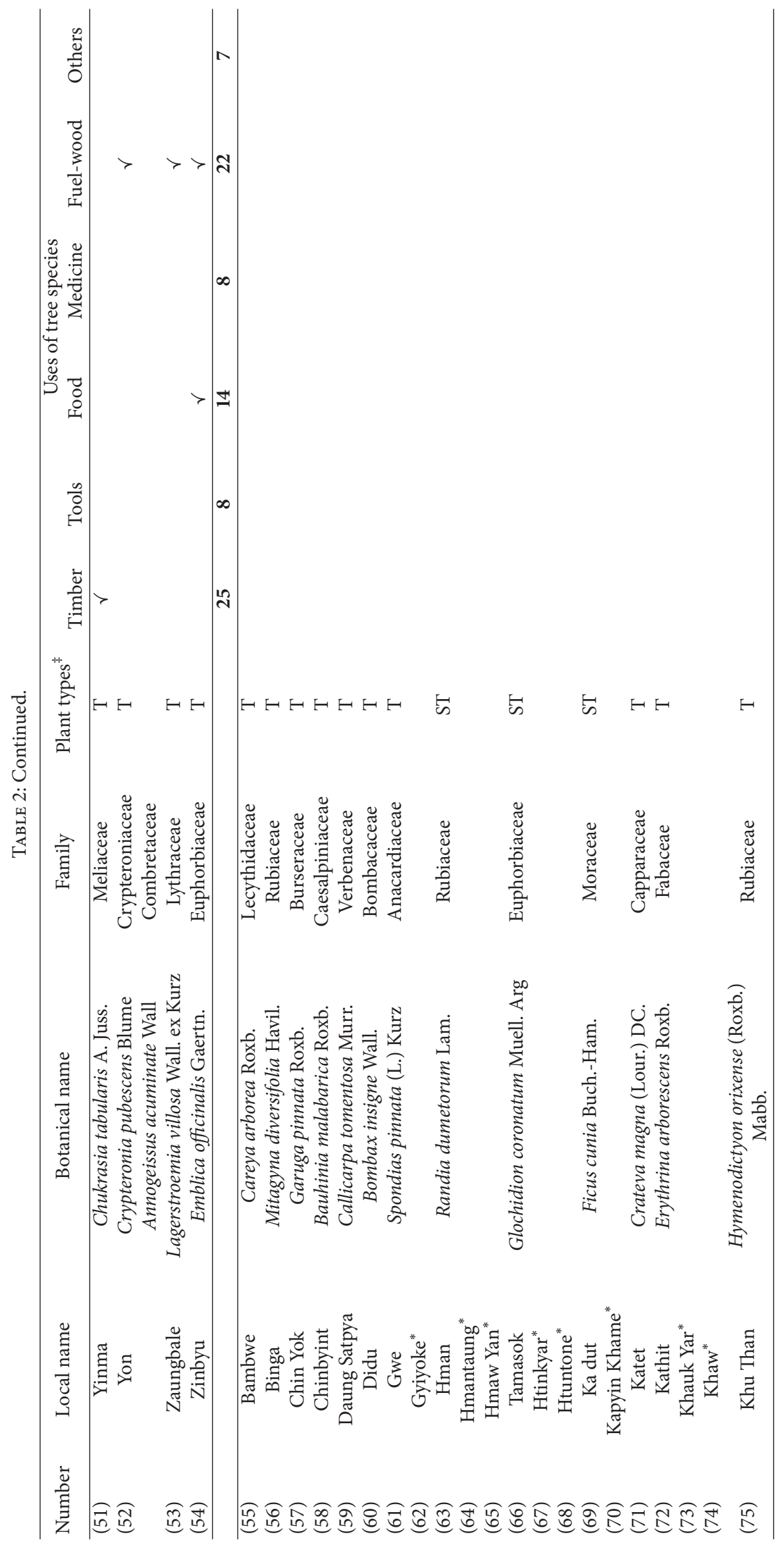




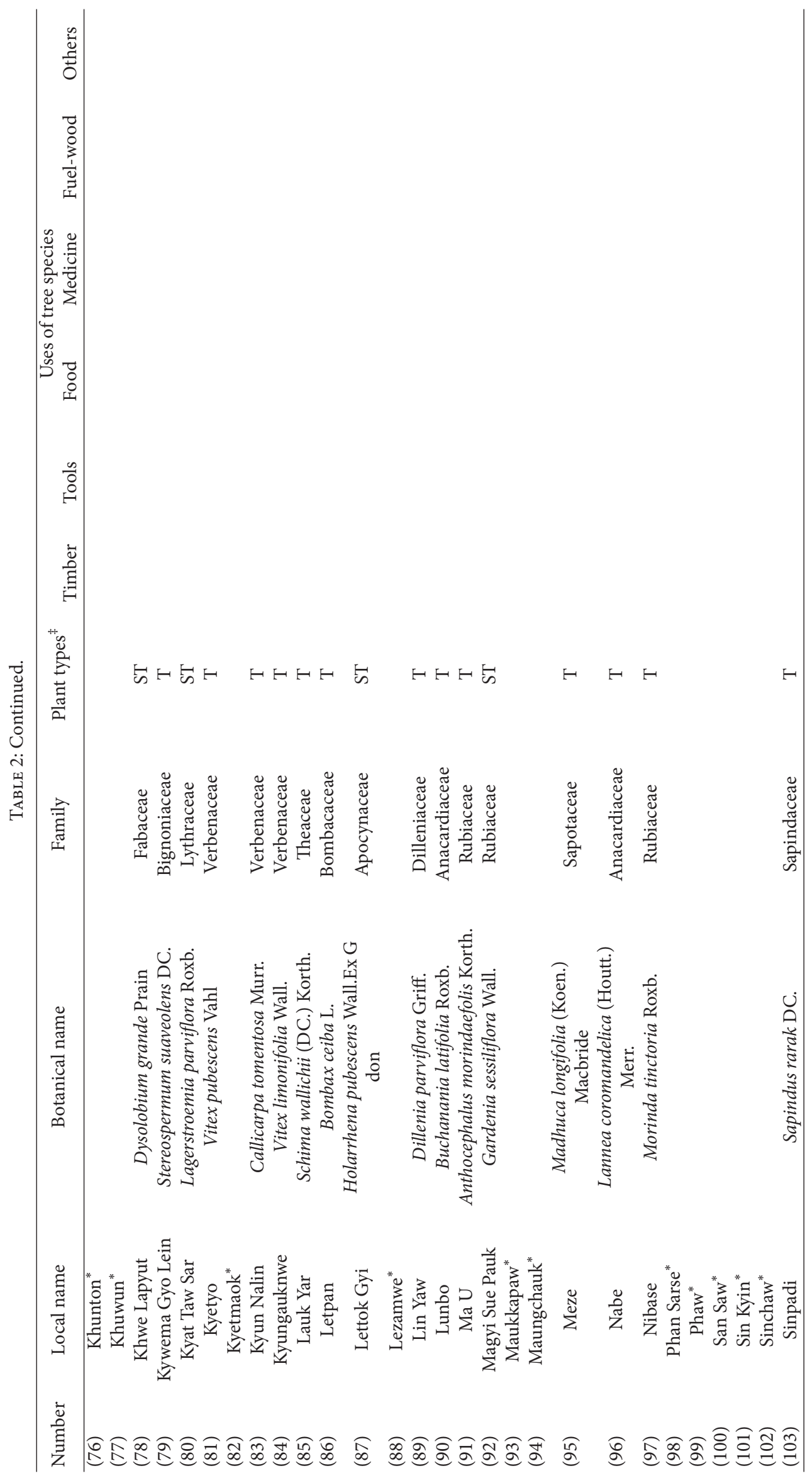




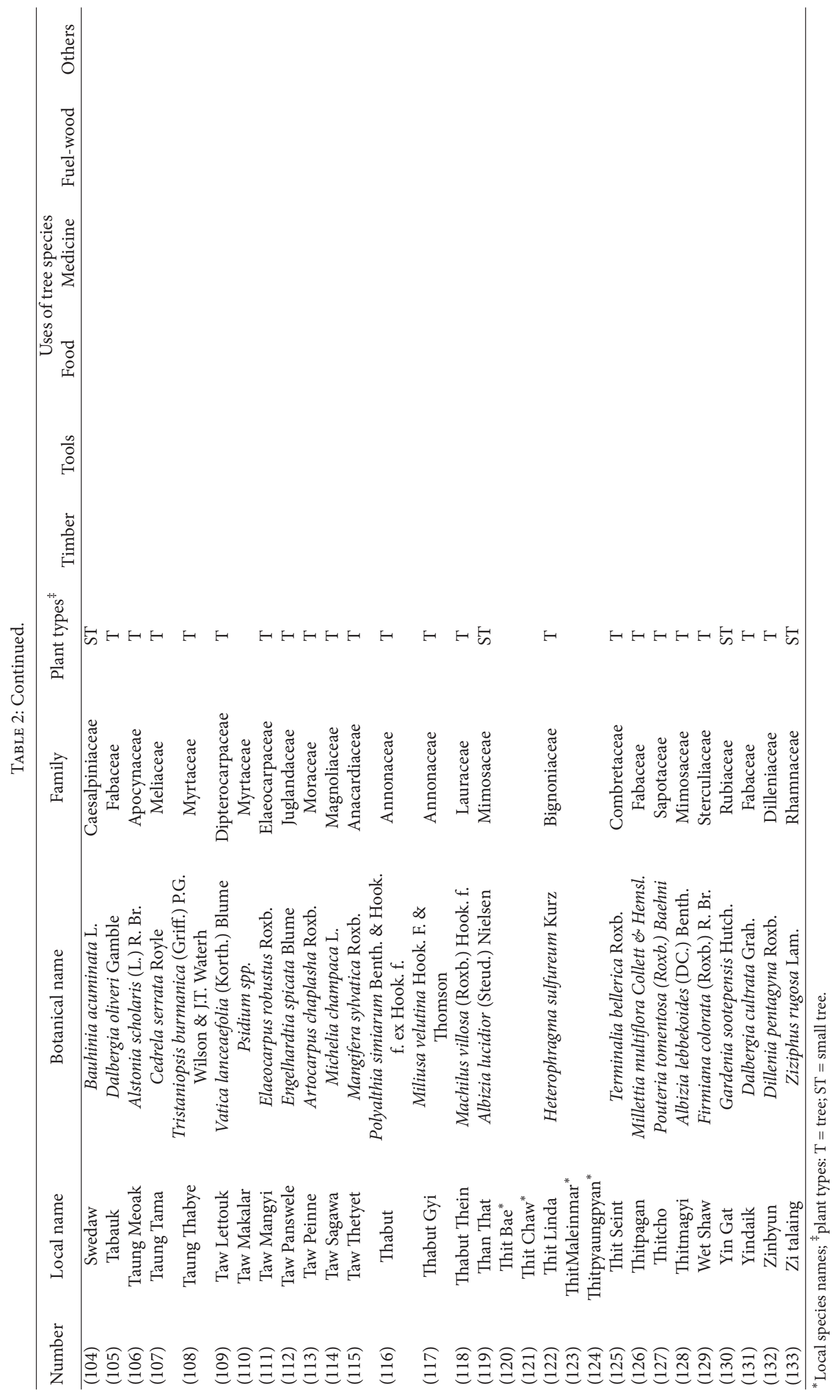




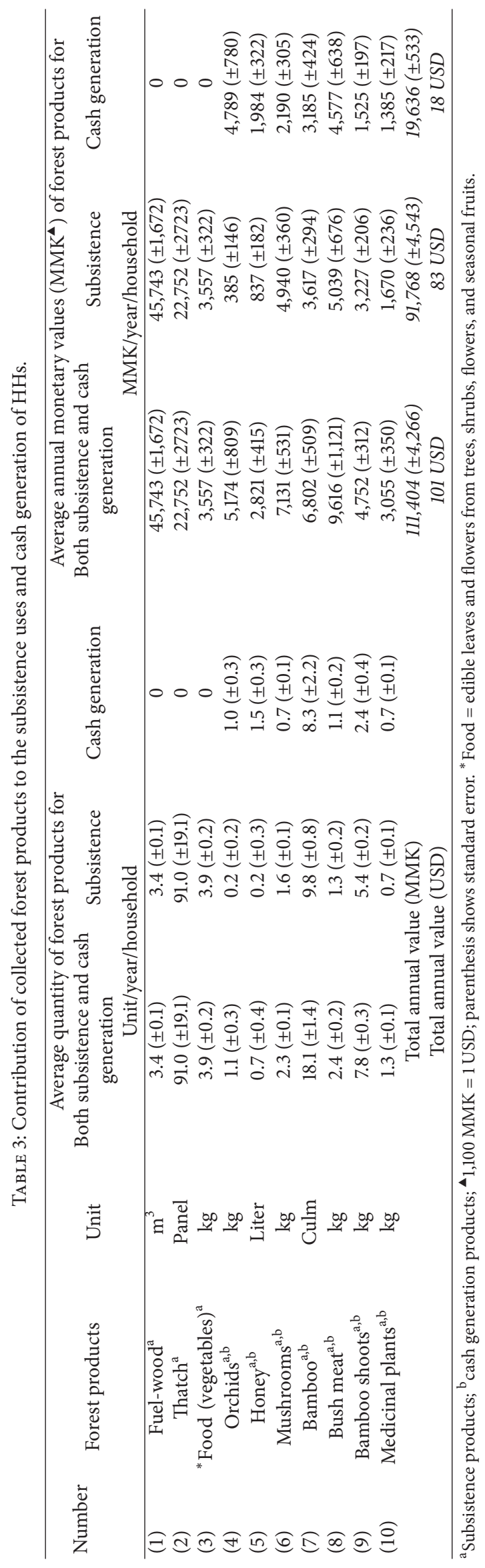


TABLE 4: Average annual total household cash income contribution by household activities (MMK* , 000).

\begin{tabular}{|c|c|c|c|c|c|c|c|}
\hline \multirow{3}{*}{$\begin{array}{l}\text { Household } \\
\text { activities }\end{array}$} & \multicolumn{7}{|c|}{ Different household income levels $(n=215)$} \\
\hline & \multicolumn{2}{|c|}{$\begin{array}{l}\text { High income } \\
\quad(n=90)\end{array}$} & \multicolumn{2}{|c|}{$\begin{array}{l}\text { Medium income } \\
\quad(n=82)\end{array}$} & \multicolumn{2}{|c|}{$\begin{array}{l}\text { Low income } \\
\qquad(n=43)\end{array}$} & \multirow[t]{2}{*}{ Kruskal-Wallis test } \\
\hline & Income & Shared \% & Income & Shared \% & Income & Shared \% & \\
\hline Agriculture & $1,515( \pm 85)$ & $69 \%$ & $880( \pm 33)$ & $77 \%$ & $256( \pm 41)$ & $66 \%$ & $X^{2}=105.4, p=0.00, \mathrm{df}=2$ \\
\hline Livestock & $169( \pm 17)$ & $8 \%$ & $96( \pm 10)$ & $8 \%$ & $56( \pm 8)$ & $14 \%$ & $X^{2}=17.76, p=0.00, \mathrm{df}=2$ \\
\hline Forest & $23( \pm 2)$ & $1 \%$ & $27( \pm 3)$ & $2 \%$ & $27( \pm 5)$ & $7 \%$ & $X^{2}=1.94, p=0.38, \mathrm{df}=2$ \\
\hline Others & $485( \pm 72)$ & $22 \%$ & $133( \pm 31)$ & $12 \%$ & $51( \pm 23)$ & $13 \%$ & $X^{2}=20.15, p=0.00, \mathrm{df}=2$ \\
\hline Total & \multicolumn{2}{|c|}{$2,192( \pm 67)$} & \multicolumn{2}{|c|}{$1,136( \pm 19)$} & \multicolumn{2}{|c|}{$390( \pm 38)$} & \\
\hline
\end{tabular}

Parenthesis shows standard error; ${ }^{*} 1,100 \mathrm{MMK}=1$ USD.

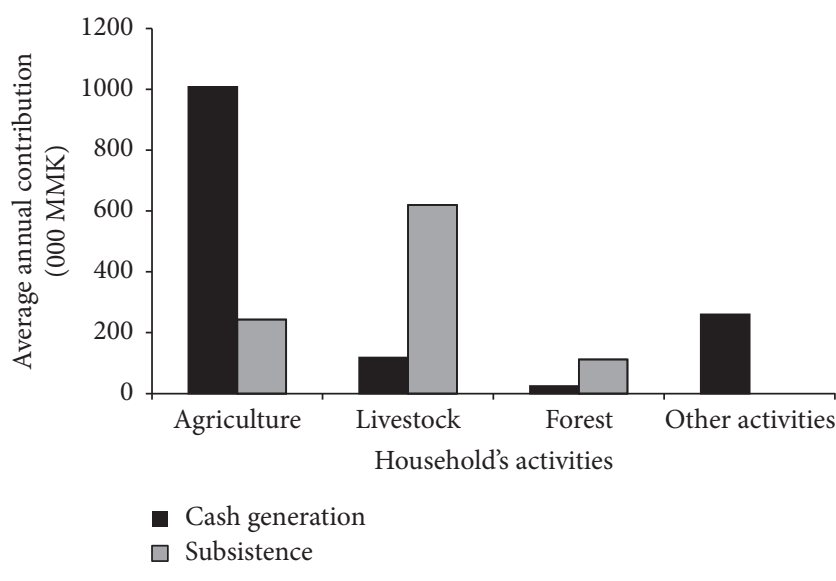

FIGURE 2: Household activities and their annual contribution to cash generation and subsistence use (MMK, 000).

forest income contribution (7\%) was found in low-income households and the lowest (1\%) was found in high-income households. The low-income households usually own less agricultural land and livestock, which makes them more dependent on forest products.

3.3. Forest Dependency. Table 5 describes the OLS regression model for forest products varieties and forest income. The sex of the HHH $(p<0.01)$ was positively correlated and statistically significant to forest products varieties. The education level of the $\mathrm{HHH}(p<0.05)$ and agricultural land area $(p<0.01)$ per household were negatively and significantly associated with forest products varieties. The number of working people $(p<0.05)$ per household, the education level of the HHH $(p<0.05)$, and the agricultural land area $(p<0.05)$ per household were negatively and significantly correlated with forest income. Agricultural income $(p<$ $0.05)$ and income from other activities $(p<0.05)$ were found to have a negative but statistically significant relation with forest income. Household characteristics such as the working people, sex, education levels, cultivating land area, and the number of livestock were found as factors influencing forest dependency in the study area.
3.4. Local People's Perceptions regarding the Forest Condition. Regarding changes in the surrounding forests, $78 \%$ of the respondents perceived that the forest area was decreasing, while $6 \%$ of the respondents perceived that the forest area was increasing and $4 \%$ of the participants perceived no changes in the last five years. Of the studied households, $12 \%$ did not give any response. Table 6 describes the perceived causes of forests depletion, the negative impacts of these causes on the collection of forest products, and the source of these causes. The five main causes were perceived as fuel-wood collection, logging (especially illegal logging), and slashand-burn agriculture in the forested areas, stone and gold mining, and forest plantations. Illegal logging (Illegal logging is defined as commits any of the following activities: felling, cutting, girdling, extracting, moving, keeping in possession unlawfully any forest produce, from a forest land (Reserved Forest and Protected Public Forest) or land at the disposal of the Government, without a permit from the person authorized to grant permission for extraction (Forest Law (1992) of Myanmar, Chapter XII: Offences and Penalties, Sections 41, 42 and 43$))(47 \%)$ and mining (41\%) were identified as the main causes of deforestation by the respondents and the impression was that these detrimental activities were being committed mainly by people and institutions from outside the communities (Table 6). Due to the significant negative effects of these two activities on households' subsistence consumption and local cash generation, people believed that action should be taken against these illegal activities.

\section{Discussion}

4.1. People's Dependence on Forest Products. The tree species that produced raw materials, the types of forest products collected, and their uses in daily life as found in this study matches with studies carried out in Sri Lanka [50] and in the Chin State of Myanmar [4]. Fifty-four tree species were identified to be mostly used by the local communities in the study area. The major demand of forest products comes from timber, fuel-wood, fodder, and bamboo (Table 1). This is a common forest product extraction pattern in other places of Myanmar [4, 38, 51, 52]. The dominance of collected trees species with small $(<0.1 \mathrm{~m} \mathrm{DBH})$ individual stems $(67 \%)$ supports the overuse of these species in the study area. 
TABLE 5: OLS regression model of collected forest products varieties for both subsistence and income of the forest products against the household characteristics and household income activities $(n=207)$.

\begin{tabular}{|c|c|c|c|}
\hline & $\begin{array}{l}\text { Collected forest products } \\
\text { varieties }\end{array}$ & Forest cash income & $\begin{array}{l}\text { Forest total income (cash } \\
\text { and subsistence) }\end{array}$ \\
\hline \multicolumn{4}{|c|}{ Coefficient } \\
\hline \multicolumn{4}{|l|}{ Household characteristics } \\
\hline Household size & $0.1( \pm 0.1)$ & $2106.5( \pm 1147.1)$ & $21395.7^{* *}( \pm 3762.2)$ \\
\hline Working people & $-0.1( \pm 0.1)$ & $-4495.0^{*}( \pm 1677.5)$ & $-24568.1^{* *}( \pm 5161.0)$ \\
\hline Sex of $\mathrm{HHH}$ & $1.2^{* *}( \pm 0.3)$ & $-1147.7( \pm 4869.8)$ & $-13289.9( \pm 15216.2)$ \\
\hline Age of $\mathrm{HHH}$ & $0.0( \pm 0.0)$ & $-182.3( \pm 130.9)$ & $-210.4( \pm 48.1)$ \\
\hline Education level of $\mathrm{HHH}$ & $-0.4^{*}( \pm 0.2)$ & $-6992.1^{*}( \pm 2468.6)$ & $-9841.7^{*}( \pm 7456.9)$ \\
\hline Agricultural land area (ha) & $-0.1^{* *}( \pm 0.0)$ & $-823.9^{*}( \pm 399.6)$ & $-2449.1^{*}( \pm 1291.4)$ \\
\hline Number of livestock & $0.1^{*}( \pm 0.1)$ & $164.1( \pm 2163.7)$ & $-1019.3( \pm 6787.6)$ \\
\hline \multirow[t]{2}{*}{ Constant } & $5.9^{* *}( \pm 0.9)$ & $71765.3^{* *}( \pm 12573.0)$ & $164065.9^{* *}( \pm 38095.7)$ \\
\hline & $\begin{array}{c}R \text {-square }=0.17, R \text {-square } \\
\text { (adjusted) }=0.14, F=5.16, P \\
>F=0.00\end{array}$ & $\begin{aligned} R \text {-square } & =0.23, R \text {-square } \\
\text { (adjusted }) & =0.17, F=4.25, P \\
> & F=0.00\end{aligned}$ & $\begin{aligned} R \text {-square } & =0.22, R \text {-square } \\
\text { (adjusted) } & =0.19, F=7.29, P \\
> & F=0.00\end{aligned}$ \\
\hline \multicolumn{4}{|l|}{ Household activities } \\
\hline Agricultural income & & $-0.0^{*}( \pm 0.0)$ & $0.0( \pm 0.3)$ \\
\hline Livestock income & & $0.0( \pm 0.0)$ & $0.0( \pm 0.3)$ \\
\hline Other incomes & & $-0.0^{*}( \pm 0.0)$ & $0.0^{*}( \pm 0.0)$ \\
\hline \multirow[t]{2}{*}{ Constant } & & $61900.9^{* *}( \pm 8351.3)$ & $62263.9^{*}( \pm 26648.1)$ \\
\hline & & $\begin{array}{c}\text { R-square }=0.19, R \text {-square } \\
\text { (adjusted) }=0.12, F=2.73, \\
P>F=0.03\end{array}$ & $\begin{array}{c}R \text {-square }=0.14, R \text {-square } \\
\text { (adjusted) }=0.09, F=3.03 \\
P>F=0.04\end{array}$ \\
\hline
\end{tabular}

${ }^{*} p<0.05 ;{ }^{* *} p<0.01$. Parenthesis shows standard error.

This suggests that the efficient cooking stoves should be provided to reduce pressure on the forest for fuel-wood collection, and forest tending activities such as improvement felling and enrichment planting must be emphasized in forest management activities to rehabilitate the forest of the study area.

The contribution of the total income of forest products to the total household income (Figure 2) is relatively low when compared with that found in other studies, which reported that the NTFPs contributed significantly to the total household income in Ethiopia [45], Nepal [46], and China [47]. Similar to other studies, the contribution from forest income to total income was found to be highest in $\mathrm{HHs}$ under the low-income group [38, 48]. This can be mainly attributed to the lack of alternative income opportunities for these $\mathrm{HH}$ s that result in increasing poverty, which in turn may be a major factor to the high dependence of communities on forest products $[8,10,53]$. HHs with a small agricultural land area, larger labor force, and low education level are more dependent on forest products (Table 5).

There are greater opportunities for income generation for educated people, which lessens their dependency on forest resources. However, the impact of education on forest dependency becomes complicated when unemployment is present in educated households causing unexpected results in variables [50]. The significant negative correlation between forest income and other activities' income was observed. It showed that the more the income from other activities outside the forest products was, the greater the savings (cash) of the local communities were, and they relied less on the forest for cash generation. The amount of agricultural land, livestock, and people's education levels were found as factors influencing the forest dependency in this studied area of the communities. Betterment of nonforest livelihood activities such as agricultural and other activities (Table 5) is suggested as one of the options to reduce forest dependency. Moreover, income-generation opportunity as a value-added opportunity for products such as bamboo and bamboo shoots (Table 1), including access to marketing channel (Table 3), should be explored for the rural people in the study area.

4.2. People's Perceptions toward Forest Products. In this study, the locals perceived shifting cultivation as one of the causes for depleting forest resources, but shifting cultivation is one of the main livelihood activities for the rural people in the area, especially the cultivating landless households in the study area (Table 4). The respondent HHs said that they recognize the impact of shifting cultivation on forest products but they expend and continue to encroach on forest area for cultivation due to decreases in crop yields and increases in $\mathrm{HH}$ demands. Agricultural cultivating methods/techniques containing ecology-based agricultural strategy as proper water and soil management methods [54] should be introduced to sustain agricultural yields. These can meet the needs of rural people despite their limited crop production and can reduce the expansion of cultivating land or conversion of forest 


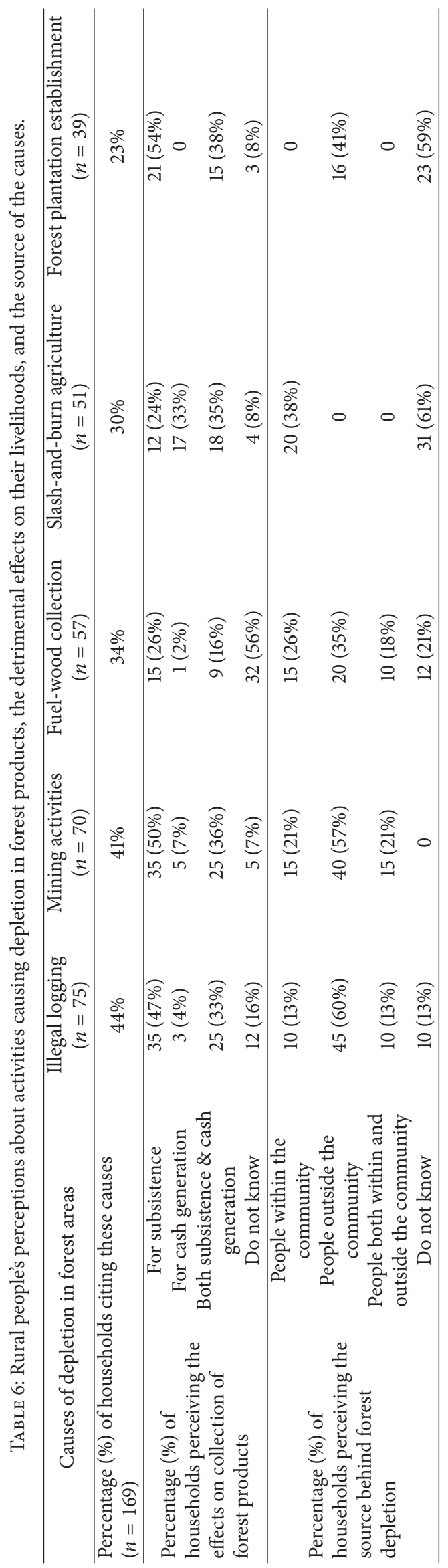


into cropland. The finding suggests that the size of shifting cultivation land should be reduced from the current level but complete elimination of shifting cultivation as implemented by the FD could negatively affect livelihoods of HHs in the study area.

The locals said that due to illegal logging and mining, which are mostly committed by the people outside their communities (Table 6), the forest's products are depleted. This negatively impacts the collection of their forest products. They claimed that, due to the forest product depletion, they have to travel long distances to collect forest products. For instance, five years ago, they could collect around $1.2 \mathrm{~m}^{3}$ of fuel-wood within one day from the forest nearby their settlement. Now, it takes three days to get the same amount of fuel-wood as only small trees $(<0.1 \mathrm{~m} \mathrm{DBH})$ are available near their settlement and these species are not preferred as fuel-wood. During the $\mathrm{HH}$ interview, an elder claimed that they used to get bush meat in a nearby forest area. Currently, they can barely find any bush meat. The animals might have lost habitat due to people's encroachment on the forest area. Other studies $[8,10,52,55]$ have also reported that illegal logging, mining, and forest land conversion activities were the main causes of the forest depletion in other places of Myanmar. The agrisilvicultural system as agroforestry practice with people's preferable multipurpose trees and common agricultural crops in shifting cultivation land is one of the better options to fulfill the needs for fuel-wood and mitigate further extraction of timber, small wood, and fodder by the local communities $[56,57]$. Aporusa spp., Cassia spp., Dipterocarpus spp., Shorea spp., Terminalia spp., and Quercus spp. are showed as potential multipurpose tree species in agroforestry for the study area (Table 2).

The FD shows the commitment and intent of the Myanmar government of ensuring sustainable forest resources both for environment and development purposes by formulating the Myanmar Forest Policy, Law, Rules, and Regulations. The findings show that the management system of the government has resulted in weak law enforcement, and the conservation activities in the existing district forest management plan are ineffective and inappropriate with area-specific issues [14]. The existing district forest management plan of the FD should be revised within the local contexts by recognizing and integrating local awareness and their dependence on forest products $[20,21,55]$ through upgrading the forest staff for patrol activities, allowing more staff, and budgeting for implementing activities [14].

We noticed that the people in the studied communities express their awareness about forest conditions and the importance of their role in forest conservation to preserve their own lives. For instance, in one of the community-entry meetings, one elder mentioned traditional practices such as not cutting trees and developing grazing land near the water sources in the forest area and not cutting all the bamboo and bamboo shoot from one clump. These practices were directly related to forest resource utilization and management but were not strictly implemented or followed by the local communities. The government needs to recognize such activities and practices of local communities [58]. Such local knowledge/practices related to forest products utilization were not discussed in this study as it requires further analysis of the studied communities.

\section{Conclusions}

The results of the study have shown that the natural forest in the Katha District plays a significant role in rural people's livelihood, serving as the main source of primary and secondary income for rural households. Institutional arrangements governing access to forests and nonforest employment opportunities are one of the important options for overall a socioeconomic improvement to reduce forest dependence of rural people. HHs with lesser cultivating land area, lower education levels, and low income tend to depend more on forest products for their daily needs in the study area. The factors influencing forest dependency among $\mathrm{HHs}$ should be considered to incorporate and revise the conservation activities in a district forest management plan at community level implementation. The study suggests that training and extension programs such as tree-based intercropping as agroforestry with the local people's preferable multipurpose tree species and value-added forest products from bamboo and bamboo shoots should be included in conservation activities of the district forest management plan. The study results are important in informing politicians and decision-makers that the locals could be considered one of the stakeholders of conservation activities and designed in the participatory strategies of the CBFM that balance conservation and utilization of forest products in not only the Katha District but also other places within Myanmar. The nature of forest dependence, harvesting and utilization of forest products from the perspective of sex, the economics of nonconsumptive natural resource use such as tourism or amenities, and the rural people's willingness to engage in conservation activities for the forest are some of the potential research arenas in the study area that would further contribute to understanding the interaction between rural people and forest products.

\section{Conflicts of Interest}

The authors declare that there are no conflicts of interest regarding the publication of this paper.

\section{Acknowledgments}

The authors are thankful to officials from the Katha District Forest Department, acknowledge the herbarium of Forest Research Institute, and acknowledge the Ministry of Natural Resources and Environmental Conservation, Myanmar, for their indispensable assistance and help during data collection. This research was carried out as part of a doctoral dissertation research financially supported by the Japan Foundation for UNU (jfUNU). The financial support provided by the Belmont Forum project "Ecosystem Scenarios Network (ScenNet)" and the nature's benefits to people research project "Predicting and Assessing Natural Capital and Ecosystem Services (PANCES)" made this study possible. The authors 
thank Dr. Mrittika Basu, Dr. Philip Vaughter, and Dr. Riyanti Djalante for their supports during the revision stage of this manuscript.

\section{References}

[1] S. Chao, Forest peoples: Numbers across the world, Peoples Program, 2012.

[2] S. M. Bwalya, "Household Dependence on Forest Income in Rural Zambia," Zambia Soc. J, vol. 2, no. 1, p. p, 2013.

[3] A. Angelsen, P. Jagger, R. Babigumira et al., "Environmental income and rural livelihoods: a global-comparative analysis," World Development, vol. 64, no. 1, pp. S12-S28, 2014.

[4] P. S. Aung, Y. O. Adam, J. Pretzsch, and R. Peters, "Distribution of forest income among rural households: A case study from Natma Taung national park, Myanmar," Forests, Trees and Livelihoods, vol. 24, no. 3, pp. 190-201, 2015.

[5] Y. O. Adam, J. Pretzsch, and D. Pettenella, "Contribution of Non-Timber Forest Products livelihood strategies to rural development in drylands of Sudan: Potentials and failures," Agricultural Systems, 2013.

[6] K. Tint, O. Springate-Baginski, and M. K. K. Gyi, Community forestry in Myanmar: progress potentials, Community forestry in Myanmar, progress potentials, 2011.

[7] Forest Department of Myanmar, "Brief Notes on Forestry Sector," 2016.

[8] Forest Department of Myanmar, "Global Forest Resources Assessment 2010 Country Report: Myanmar," in Global Forest Resources Assessment 2010, p. 52, FAO, 2010.

[9] Food and Agricultural Organization of the United Nations (FAO), “Global Forest Resources Assessment 2015, 2015.

[10] Forest Department of Myanmar, SagaingRegion Forest Working Plan (2010-16), Myanmar, 2016.

[11] FAO, "Global Forest Resources Assessment 2005: Progress towards sustainable forest management," 2016.

[12] Forest Department of Myanmar, "National Biodiversity Strategy and Action Plan 2015-2020," 2015.

[13] C. Uhl and I. C. Guimaraes Vieira, "Ecological impacts of selective logging in the Brazilian Amazon: a case study from the Paragominas region of the state of Para," Biotropica, vol. 21, no. 2, pp. 98-106, 1989.

[14] U. M. Aung, "Policy and practice in Myanmar's protected area system," Journal of Environmental Management, vol. 84, no. 2, pp. 188-203, 2007.

[15] M. Rao, A. Rabinowitz, and S. Tun Khaing, "Status review of the protected-area system in Myanmar, with recommendations for conservation planning," Conservation Biology, vol. 16, no. 2, pp. 360-368, 2002.

[16] E. Wollenberg and A. S. Nawir, "Estimating the incomes of people who depend on forests in," in Estimating the incomes of people who depend on forests, E. Wollenberg and A. Ingles, Eds., Centre for International Forestry Research, Bogor, Indonesia, 1998.

[17] B. Belcher, M. Ruíz-Pérez, and R. Achdiawan, "Global patterns and trends in the use and management of commercial NTFPs: implications for livelihoods and conservation," World Development, vol. 33, no. 9, pp. 1435-1452, 2005.

[18] K. Heubach, R. Wittig, E.-A. Nuppenau, and K. Hahn, “The economic importance of non-timber forest products (NTFPs) for livelihood maintenance of rural west African communities: a case study from northern Benin," Ecological Economics, vol. 70, no. 11, pp. 1991-2001, 2011.

[19] A. Angelsen and S. Wunder, "Exploring the forest poverty link: key concepts, issues and research implications," Economist, vol. 40, p. 68, 2003.

[20] M. Cocks, A. Dold, and I. Grundy, "Challenges Facing a Community Structure to Implement CBNRM in the Eastern Cape," African Stud. Q, vol. 5, no. 3, pp. 57-71, 2001.

[21] M. Meshack and J. Odera, "Challenges and opportunities in community based dryland natural resources management," in Proceedings of the in African-economic Conference, p. 11, 2007.

[22] F. Berkes, J. Colding, and C. Folke, "Nature and society through the lens of resilience: toward a human-in-ecosystem perspective," in Navigating Social - Ecological Systems: Building Resilience for Complexity and Change, F. Berkes, J. Colding, and C. Folke, Eds., Cambridge University Press, Cambridge, UK, 2002.

[23] S. T. Asah, A. D. Guerry, D. J. Blahna, and J. J. Lawler, "Perception, acquisition and use of ecosystem services: Human behavior, and ecosystem management and policy implications," Ecosystem Services, vol. 10, pp. 180-186, 2014.

[24] T. Furusawa, M. Q. Sirikolo, M. Sasaoka, and R. Ohtsuka, "Interaction between forest biodiversity and people's use of forest resources in Roviana, Solomon Islands: Implications for biocultural conservation under socioeconomic changes," Journal of Ethnobiology and Ethnomedicine, vol. 10, no. 1, article no. 10, 2014.

[25] C. P. Helito, M. K. Demange, and M. B. Bonadio, "Anatomy and histology of the knee anterolateral ligament," Orthopaedic Journal of Sports Medicine, vol. 1, no. 7, 2013.

[26] T. Dietz, E. Ostrom, and P. C. Stern, "The Struggle to Govern the Commons," Science, vol. 302, no. 5652, pp. 1907-1912, 2003.

[27] C. D. Becker and E. Ostrom, "Human ecology and resource sustainability: The importance of institutional diversity," Annual Review of Ecology, Evolution, and Systematics, vol. 26, no. 1, pp. 113-133, 1995.

[28] Forest Department of Myanmar, "Instruction for inventory 2014-15," 2014.

[29] S. Doheny and P. Milbourne, "Community, rurality, and older people: Critically comparing older people's experiences across different rural communities," Journal of Rural Studies, vol. 50, pp. 129-138, 2017.

[30] N. Byron and M. Arnold, "What futures for the people of the tropical forests?" World Development, vol. 27, no. 5, pp. 789-805, 1999.

[31] T. O. McShane and M. P. Wells, Getting Biodiversity Projects to Work, Columbia University Press, New York Chichester, West Sussex, 2004.

[32] S. H. Ibrahim, "Sustainability Assessment and Identification of Determinants in Community-Based Water Supply Projects using Partial Least Squares Path Model," Journal of Sustainable Development of Energy, Water and Environment Systems, vol. 5, no. 3, pp. 345-358, 2017.

[33] B. P. Kaltenborn, J. D. Linnell, E. G. Baggethun, H. Lindhjem, J. Thomassen, and K. M. Chan, "Ecosystem Services and Cultural Values as Building Blocks for 'The Good life'. A Case Study in the Community of Røst, Lofoten Islands, Norway," Ecological Economics, vol. 140, pp. 166-176, 2017.

[34] Population Department of Myanmar, The 2014 Myanar Population and Housing Census Sagaing Region Census Report Volume 3-E, Myanmar, 2015. 
[35] O. M. Agbogidi, "Ethno-botanical survey of the non-timber forest products in Sapele Local Government Area of Delta State, Nigeria," African Journal of Plant Science, vol. 4, no. 3, pp. 183$189,2010$.

[36] B. Aliyu, Some ethno medicinal plants of the Savannah regions of West Africa: description and phytochemicals, Triumph Publishing Company Ltd, 2006.

[37] Labour Department of Myanmar, Myanmar Labour force, child labour and school-to-work Transition Survey-2015, 2016.

[38] K. T. Moe and J. Liu, "Economic Contribution of Non-timber Forest Products (NTFPs) to Rural Livelihoods in the Tharawady District of Myanmar," International Journal of Sciences, vol. 2, no. 01, pp. 12-21, 2016.

[39] M. Browning, P.-A. Chiappori, and A. Lewbel, "Estimating consumption economies of scale, adult equivalence scales, and household bargaining power," Review of Economic Studies, vol. 80, no. 4, Article ID rdt019, pp. 1267-1303, 2013.

[40] W. Cavendish, "Quantitative methods for estimating the economic value of resources use to rural households," in Uncovering the Hidden Harvest: Valuation Methods for Woodland And Forest Resources, p. 51, Earthscan Publication, 2002.

[41] C. Bailey, M. Dubois, and A. B. Brodbeck, Matching Local Resources to Local Needs: Forestry and Community Development in Alabama's Black Belt, Sacramento, California, Ca, USA, 2004.

[42] J. Kusel, "Assessing well-being in forest-dependent communities," USDA Forest Service - General Technical Report PNW, no. 566, pp. 81-104, 2003.

[43] N. Lee Peluso, C. R. Humphrey, and L. P. Fortmann, "The rock, the beach, and the tidal pool: People and poverty in natural resource-dependent areas," Society \& Natural Resources, vol. 7, no. 1, pp. 23-38, 1994.

[44] R. Stedman, W. White, M. Patriquin, and D. Watson, "Measuring community forest-sector dependence: Does method matter?" Society \& Natural Resources, vol. 20, no. 7, pp. 629-646, 2007.

[45] B. Teshome, H. Kassa, Z. Mohammed, and C. Padoch, "Contribution of dry forest products to household income and determinants of forest income levels in the Northwestern and Southern Lowlands of Ethiopia," Natural Resources, vol. 06, no. 05, pp. 331-338, 2015.

[46] D. B. T. Magar, "Contribution of Non-Timber Forest Products in the Livelihood of Chepang Community," 2008.

[47] P. Kamanga, P. Vedeld, and E. Sjaastad, "Forest incomes and rural livelihoods in Chiradzulu District, Malawi," Ecological Economics, vol. 68, no. 3, pp. 613-624, 2009.

[48] S. P. Kar and M. G. Jacobson, "NTFP income contribution to household economy and related socio-economic factors: lessons from Bangladesh," Forest Policy and Economics, vol. 14, no. 1, pp. 136-142, 2012.

[49] K. Armstrong, "A Checklist of the Trees, Shrubs, Herbs, and Climbers of Myanmar . : Smithsonian Institution. Contributions from the United States National Herbarium, Vol. 45. 2003. 590pp. ISSN 0097 1618. Available free of charge while supplies last," in Edinburgh Journal of Botany, W. J. Kress, A. D. Robert, F. Ellen, and Y. Y. K. Daw, Eds., vol. 45, pp. 1-590, Washington, wash, USA, 2003.

[50] P. Illukpitiya and J. F. Yanagida, "Role of income diversification in protecting natural forests: Evidence from rural households in forest margins of Sri Lanka," Agroforestry Systems, vol. 74, no. 1, pp. 51-62, 2008.
[51] M. T. Toe and M. Kanzaki, Livelihood of Local Communities and Their Dependence on Dry Forests in The Central Dry Zone, Myanmar, vol. 5, 2017.

[52] M. Songer, Myint Aung, B. Senior, R. Defries, and P. Leimgruber, "Spatial and temporal deforestation dynamics in protected and unprotected dry forests: A case study from Myanmar (Burma)," Biodiversity and Conservation, vol. 18, no. 4, pp. 10011018, 2009.

[53] I. Khaine, S. Y. Woo, and H. Kang, "A study of the role of forest and forest-dependent community in Myanmar," Forest Science and Technology, vol. 10, no. 4, pp. 197-200, 2014.

[54] T. Tachibana, T. M. Nguyen, and K. Otsuka, "Agricultural intensification versus extensification: A case study of deforestation in the Northern-hill region of Vietnam," Journal of Environmental Economics and Management, vol. 41, no. 1, pp. 44-69, 2001.

[55] B. Singh and M. M. Keitsch, "Cultural Sustainability and Space a Comparison of two Cases in Kathmandu, Nepal," Sustainable Development, vol. 24, no. 5, pp. 307-318, 2016.

[56] P. Wangpakapattanawong, "Agroforestry in rice-production landscapes in Southeast Asia a practical manual," FAO and ICRAF, 2017.

[57] P. R. Foroughbakhch, J. H. Piñero, M. A. A. Vázquez, and M. L. C. Avila, "Use of multipurpose trees and shrubs in forestry and agroforestry systems in northeastern Mexico," Handbook on Agroforestry: Management Practices and Environmental Impact, pp. 37-95, 2009.

[58] L. Moscovich, "Decentralization and Local Government in Latin America' Draft version 2014," in Latin American Democracy: Emerging reality or endangered species? L. Richard . Millett, S. Jennifer . Holmes y Orlando J Pérez ( comps ) Latin, O. J. Perez, and Second., Eds., pp. 1-34, Routledge, 2nd edition, 2014. 

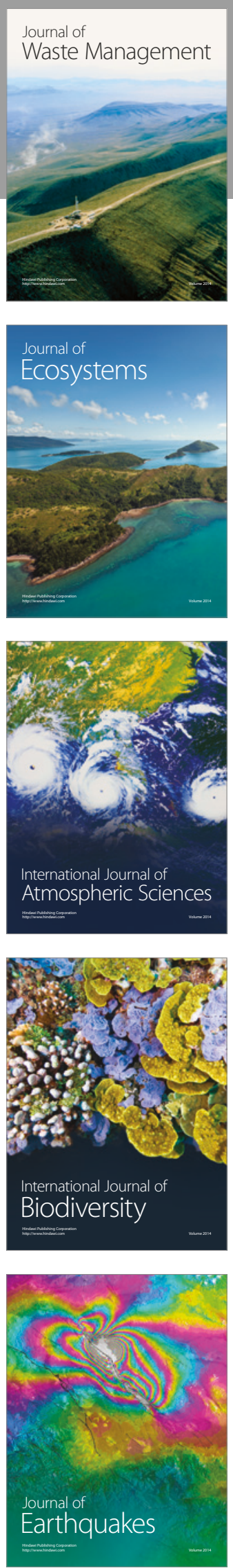
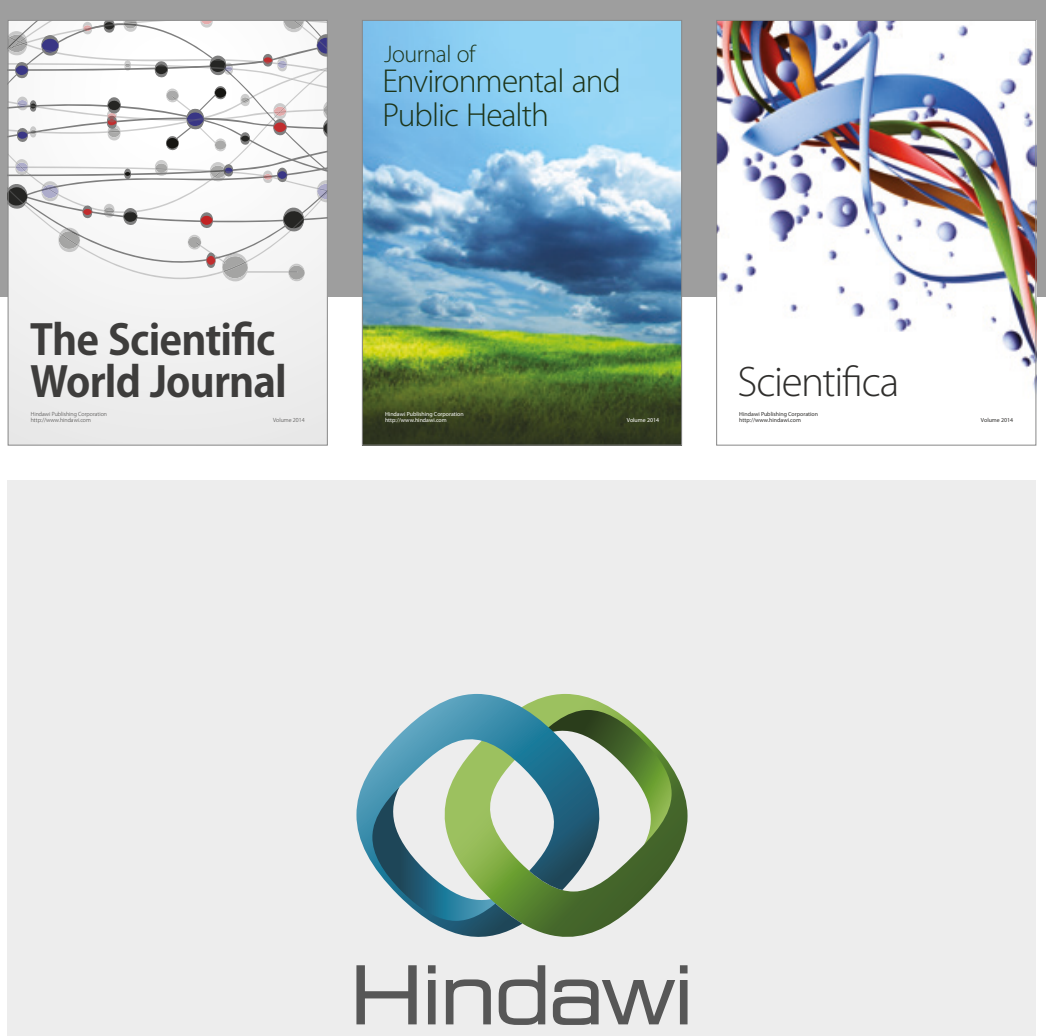

Submit your manuscripts at

https://www.hindawi.com
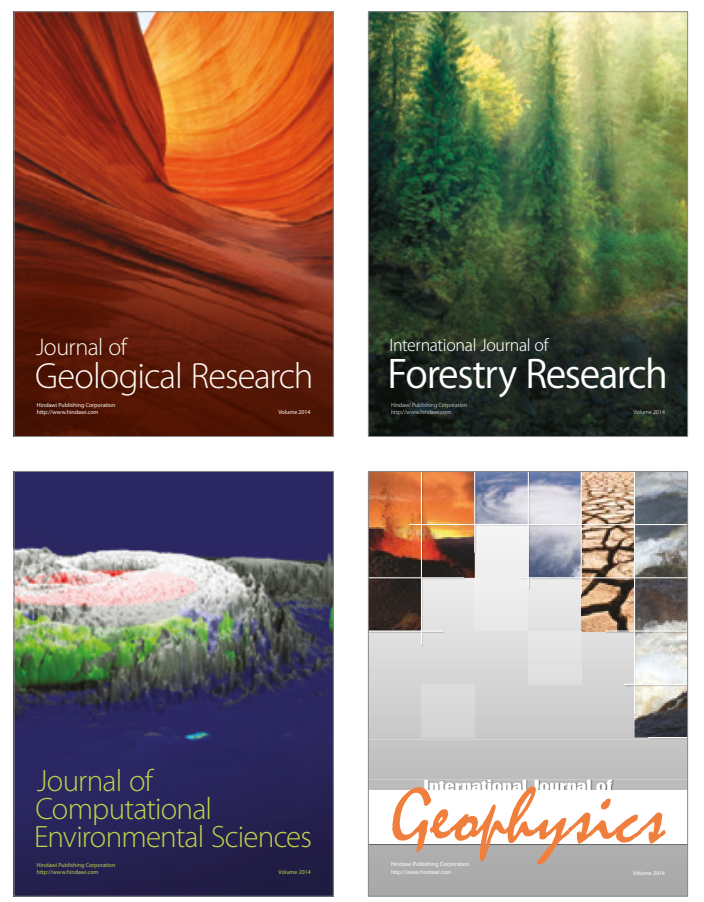
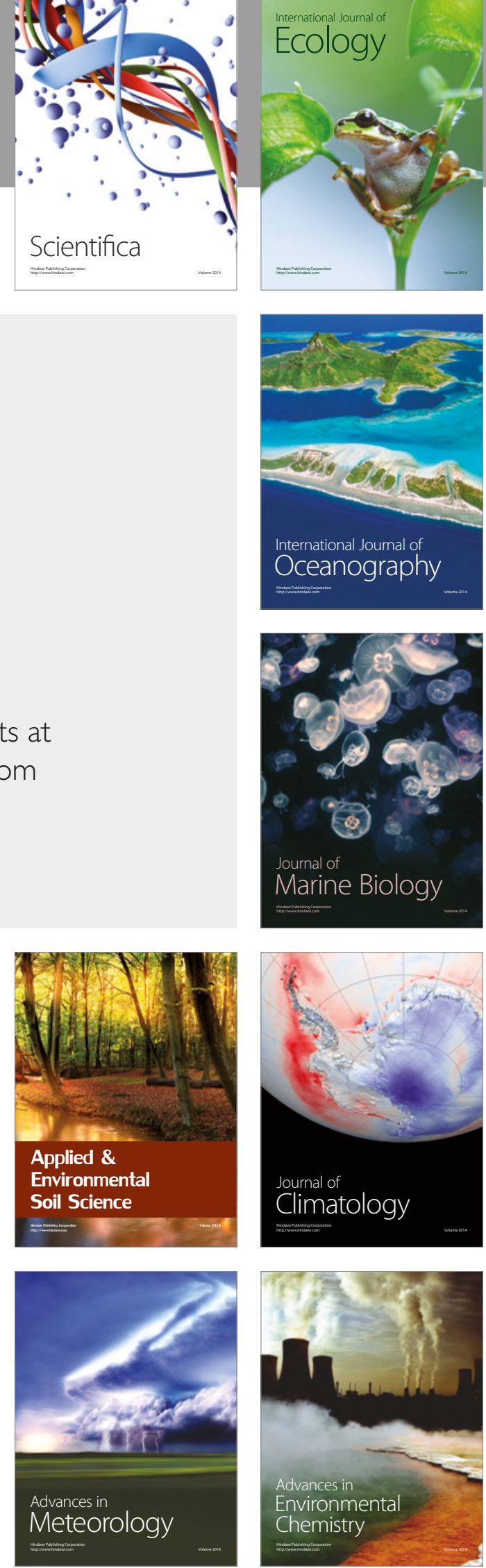